\title{
Borrelia Burgdorferi IgG Antibody Measurement
}

National Cancer Institute

\section{Source}

National Cancer Institute. Borrelia Burgdorferi Ig G Antibody Measurement. NCI

Thesaurus. Code C122100.

The determination of the amount of Borrelia burgdorferi Ig G antibody present in a sample. 